\title{
Molecular Detection of Foot and Mouth Disease Virus (FMDV) from 2017 Outbreaks in Punjab by RT-PCR and RT-LAMP Assays
}

Farah Haidar $^{1}$, Usman Waheed ${ }^{1 *}$, Syed Ehtisham-ul-Haque ${ }^{1}$ and Muhammad Arshad ${ }^{2}$

${ }^{1}$ Department of Pathobiology (Microbiology Section), College of Veterinary and Animal Sciences, Jhang, Pakistan

${ }^{2}$ Department of Biochemistry, College of Veterinary and Animal Sciences, Jhang, Pakistan

"Corresponding author: Usman Waheed, Department of Pathobiology (Microbiology Section), College of Veterinary and Animal Sciences, Jhang, Pakistan, Tel: +92-300-7658010; E-mail: usman.waheed@uvas.edu.pk

Rec date: January 09, 2018; Acc date: January 22, 2018; Pub date: January 23, 2018

Copyright: (c) 2018 Haidar F, et al. This is an open-access article distributed under the terms of the Creative Commons Attribution License, which permits unrestricted use, distribution, and reproduction in any medium, provided the original author and source are credited.

\section{Retraction Note:}

The article entitled "Molecular Detection of Foot and Mouth Disease Virus (FMDV) from 2017 Outbreaks in Punjab by RT-PCR and RT-LAMP Assays," has been accepted for publication in the Journal of Veterinary Science \& Technology considering the statements provided in the article as personal opinion of the author which was found not having any conflict or biasness towards anything. As the article was a perspective one, information provided by the author was considered as an opinion to be expressed through publication. Publisher took decision to make the article online solely based on the reviewers suggestion which considered the article not but a personal opinion of the author. However, it is found that the author have some personal concerns and issues, therefore, being retracted from the journal. 